УДК $343.213+343.23$

DOI https://doi.org/10.32849/2663-5313/2020.5.50

Юлія Шопіна,

аспірант кафедри кримінального права

Національної академії внутрішніх справ

\title{
ОБ'ЄКТИВНА СТОРОНА ЗЛОЧИНІВ, ПЕРЕДБАЧЕНИХ СТАТТЯМИ 131, 132, 134, 139-145 КРИМІНАЛЬНОГО КОДЕКСУ УКРАЇНИ
}

У статті досліджено об'єктивну сторону злочинів, які передбачені ст. ст. 131, 132, 134, 139-145 Кримінального кодексу України. Звернено увагу на те, що саме через ознаки об'єктивної сторони здебільшого визначаються об'єкт і суб'єктивна (внутрішня) сторона складу злочину. Здійснюється конкретизачія ознак об'єктивної сторони складів злочинів щодо окремих статей Особливої частини КК України, які передбачають кримінальну відповідальність медичного або фармачевтичного прачівника за вчинення злочину, пов'язаного з виконанням професійних обов'язків. Виділено злочини, що посягають на права особи у сфері медичної діяльності виключно дією (ст. ст. 131, 134, 142, ч. ч. 2-4 cm. 143 КК Украйни), й такі, що можуть бути вчинені альтернативно дією чи бездіяльністю (cm. cm. 132, 145, 139, 140, ч. 1 cm. 143 КК України). Зроблено висновок про те, що об'єктивній стороні деяких посягань на правопорядок у сфері медичної діяльності властива «змішана бездіяльність», коли без акту бездіяльності дії особи не мають значення в об'єктивній стороні злочину, й навпаки (cm. cm. 138, 141, 144 КК України). Сформульовано рекомендачії щодо кваліфікаиії таких злочинів з урахуванням зазначених особливостей. Визначено, що з об'єктивної сторони злочин, передбачений ст. 139 КК Украӥни, виражається у бездіяльності, оскільки медичний прачівник, який, відповідно до встановлених правил, зобов'язаний надавати допомогу хворому, без поважних причин не робить иього. Під бездіяльністю у кримінальному праві зазвичай розуміється суспільно небезпечна вольова поведінка особи, що полягає у невиконанні належного, тобто того обов'язку, який особа повинна була й могла виконати. Ненадання допомоги хворому може виражатись як у повній відмові від ї надання, так і в ненаданні допомоги в обсязі, необхідному в конкретній ситуаиії. Зроблено висновок, що об'єктивна сторона складу злочину має велике значення для правильної кваліфікачії конкретного злочину; відмежування одного злочину від іншого, а також від інших правопорушень, насамперед адміністративних; правильного визначення з урахуванням пом'якшуючих $і$ обтяжуючих обставин, які виявляються під час дослідження саме чієі сторони, ступеня тяжкості вчиненого злочину, зрештою, постановлення справедливого судового вироку.

Ключові слова: суспільно небезпечне діяння, суспільно небезпечні наслідки, причинний зв’язок, місце, час, обстановка, спосіб, засоби та знаряддя вчинення злочину.

Постановка проблеми. Сутність злочину полягає в суспільно небезпечному діянні, яке є основною, а також обов'язковою ознакою об'єктивної сторони. Будь-який злочин як суспільно небезпечне діяння спричиняє негативні зміни в реальній дійсності, тягне за собою суспільно небезпечні наслідки, які полягають у заподіянні шкоди об'єкту кримінально-правової охорони. Безнаслідкових злочинів не буває, адже, якщо б те чи інше діяння не спричиняло суспільно небезпечних наслідків, його не потрібно було б криміналізувати. Водночас не будь-яка заподіювана злочином шкода вважається суспільно небезпечними наслідками як ознакою складу злочину. Особливість таких наслідків полягає в тому, що вони піддаються встановленню в порядку, закріпленому кримінальнопроцесуальним законодавством. Проте в кримінальному законі суспільно небезпечні наслідки як обов'язкова ознака об'єктивної сторони складу конкретного злочину позначаються по-різному. 3 огляду на те, що нині ознаки об'єктивної сторони складу злочинів, передбачених ст. ст. 131, 132, 134, 139 145 КК України, не є достатньою мірою проаналізованими науковцями, а також на те, що здебільшого присутнє дослідження застарілих норм КК України, вбачається актуальність у конкретизації ознак об'єктивної сторони складів злочинів щодо окремих статей Особливої частини КК України, які передбачають кримінальну відповідальність медичного або фармацевтичного працівника за вчинення злочину, пов'язаного з виконанням професійних обов'язків.

Дослідженням об'єктивної сторони складів злочинів, передбачених ст. ст. 131, 
132, 134, 139-145 Особливої частини КК України, займалися, зокрема, В.В. Бабаніна, В.В. Балабко, О.Г. Берило В.А. Глушков, O.M. Джужа, C.P. Дутчак, А.В. Савченко, Е.М. Кісілюк, Т.Ю. Тарасевич, І.М. Філь, Г.В. Чеботарьов. Проте, незважаючи на їх значний внесок до вирішення цієї проблематики, все ж таки залишається актуальним дослідження ознак об'єктивної сторони вищезазначених складів злочинів.

Метою статті $€$ дослідження ознак об'єктивної сторони злочинів, передбачених у ст. ст. 131, 132, 134, 139-145 Особливої частини КК України.

Виклад основного матеріалу. Об'єктивна сторона злочинів, що вчиняються медичним або фармацевтичним працівником у сфері професійної діяльності, зокрема, характеризується такими ознаками:

- суспільно небезпечне діяння, яке виражається в дії або бездіяльності;

- суспільно небезпечні наслідки;

- причинний зв'язок між суспільно небезпечним діянням (дією або бездіяльністю) й суспільно небезпечними наслідками;

- об'єктивні обставини, з якими пов'язане діяння (місце, час, обстановка, спосіб, засоби та знаряддя вчинення злочину).

Ознаки об'єктивної сторони складу злочину залежно від диспозицій статей Особливої частини КК України можна поділити на обов'язкові та факультативні.

Залежно від того, обов'язковими чи факультативними (необов'язковими) ознаками об'єктивної сторони є суспільно небезпечні наслідки (залежать від конструкції складу злочину), злочини поділяються на злочини з формальним складом і злочини з матеріальним складом.

Під поняттям «злочини 3 матеріальним складом» необхідно розуміти такі злочини, для об'єктивної сторони яких диспозиція статті КК України вимагає встановлення не тільки діяння (дії або бездіяльності), але й обов'язкового настання суспільно небезпечних наслідків [1, с. 376].

Серед досліджуваних діянь до злочинів із матеріальним складом можна віднести злочини, передбачені ст. 131, ч. 2 ст. 134 , ч. 2 ст. 139 , ст. 140 , ст. 141 , ст. 142 , ст. 145 КК, а до злочинів із формальним складом - злочини, передбачені ст. 132, ч. 1 ст. 134, ч. 1 ст. 139, ст. 143, ст. 144 КК України.

Об'єктивна сторона злочину, передбаченого ст. 131 КК України, полягає в неналежному виконанні професійних обов'язків внаслідок недбалого чи несумлінного ставлення до них, що спричинило зараження особи вірусом імунодефіциту людини чи іншої невиліковної інфекційної хвороби. За ст. 131 КК України можуть бути кваліфіковані, зокрема, такі діяння, як переливання потерпілому крові (iі компонентів) ВІЛ-інфікованого без проведення лабораторної діагностики на наявність ВІЛінфекції; використання інших біологічних рідин, клітин, органів і тканин без їх лабораторного дослідження на ВІЛ-інфекцію; використання нестерильних, належним чином непродезінфікованих медичних інструментів і шприців; незабезпечення керівництвом закладу охорони здоров'я персоналу цього закладу необхідними засобами захисту згідно зі встановленими Кабінетом Міністрів України переліком та нормативами.

Кваліфікуючою ознакою цього злочину $є$ зараження двох чи більше осіб. Як правило, зараження людини ВІЛ або іншою невиліковною хворобою здебільшого призводить до смерті цієї людини. Слід зазначити, що в зону ризику від такого злочину досить часто потрапляють неповнолітні особи, що свідчить про значно більшу суспільну небезпеку вчиненого діяння, тому вважаємо за доцільне до кваліфікуючих ознак цього злочину віднести таку кваліфікуючу ознаку, як зараження неповнолітньої особи.

У зв'язку з цим необхідно внести зміни до диспозиції ч. 2 ст. 131 КК України шляхом зазначення такого: «те саме діяння, якщо воно спричинило зараження неповнолітньої особи або двох чи більше осіб» [2, с. 402].

Об'єктивна сторона злочину, передбаченого ст. 132 КК України, полягає в розголошенні відомостей про наявність у особи ВІЛ-інфекції, СНІДу або іншої невиліковної хвороби за умов, що ці відомості стали відомі у зв'язку з виконанням службових або професійних обов'язків.

Об'єктивна сторона цього складу злочину включає тільки діяння у вигляді розголошення інформації, яке може бути вчинене умисно або через необережність.

Розголошення відомостей означає, що особа, яка зобов'язана зберігати відповідну інформацію в таємниці, незаконно ознайомлює з нею сторонніх осіб або своєю поведінкою створює умови, які надають стороннім особам можливість ознайомитися з відповідними відомостями. Способи розголошення відомостей можуть бути різними, на кваліфікацію вчиненого за ст. 132 КК України злочину вони не впливають. Це може бути повідомлення у розмовах, виступах, наукових статтях, на лекціях, надання сторонній особі документів, що містять відповідні відомості, або недбале зберігання чи втрата таких документів тощо. Злочин вважається закінченим з моменту, коли відповідні відомості стали 
відомі особі, яка не повинна була їх знати. Можливі інші негативні наслідки (самогубство потерпілого, вимушене звільнення його 3 роботи тощо), які повинні враховуватись під час призначення винному покарання [3, c. 11]

Якщо ж розголошуючи ці відомості, винна особа мала на меті довести потерпілу особу до самогубства, то ці дії вже необхідно кваліфікувати за ст. 120 КК України «Доведення до самогубства». Однак розголошення, яке передбачене у ст. 132, безпосередньо не загрожує ні життю, ні здоров'ю особи.

3 об'єктивної сторони злочин, передбачений ст. 134 КК України, може мати такі форми:

1) проведення аборту особою, яка не має спеціальної медичної освіти (ч. 1 ст. 134 КК України);

2) примушування до аборту без добровільної згоди потерпілої особи (ч. 2 ст. 134 КК України);

3) незаконне проведення аборту, що спричинило тривалий розлад здоров'я, безплідність або смерть потерпілої особи (ч. 3 ст. 134 КК України);

4) примушування до стерилізації без добровільної згоди потерпілої особи (ч. 4 ст. 134 КК України);

5) дія, передбачена частиною четвертою цієї статті, якщо вона спричинила смерть потерпілої особи чи інші тяжкі наслідки (ч. 5 ст. 134 КК України).

Необхідно також звернути увагу на те, що оскільки аборт - це медичне втручання, яке має на меті переривання вагітності, то диспозицією ст. 134 КК України не охоплюються випадки, коли викидень стає результатом надання неякісної медичної допомоги вагітній жінці. За таких обставин вбачаються підстави для інкримінування винному медичному працівнику ст. 140 КК України [4, c. 143$]$

3 об'єктивної сторони злочин, передбачений ст. 139 КК України, виражається у бездіяльності, оскільки медичний працівник, який, відповідно до встановлених правил, зобов'язаний надавати допомогу хворому, без поважних причин не робить цього. Під бездіяльністю у кримінальному праві зазвичай розуміється суспільно небезпечна вольова поведінка особи, що полягає у невиконанні належного, тобто того обов'язку, який особа повинна була й могла виконати. Ненадання допомоги хворому може виражатись як у повній відмові від її надання, так і в ненаданні допомоги в обсязі, необхідному в конкретній ситуації.

У розглядуваній ситуації доречно говорити про «змішану бездіяльність», яка є без- діяльністю, поєднаною з дією, яка самостійного кримінально-правового значення не має. Наприклад, те, що бездіяльність під час злочинного ненадання медичним працівником допомоги хворому може бути як «чистою», так і «змішаною», проявляється, зокрема, в неправильному вжитті медичних заходів; огляді хворого, який насправді потребує госпіталізації, або постановці такого діагнозу особі, з якого випливає, що вона нібито не потребує допомоги. Про це зазначається безпосередньо в самій літературі [5, с. $109 ; 6$, с. 39].

За ст. 139 КК України слід кваліфікувати, зокрема, нез'явлення до хворого за викликом; відмову прийняти хворого у лікувально-профілактичний заклад для надання йому першої невідкладної допомоги у разі нещасного випадку; відмову доставити хворого до лікарні; відмову надати першу невідкладну медичну допомогу пораненому або травмованому (дати потрібні ліки, провести штучне дихання або масаж серця, зупинити кровотечу тощо); поверхове, формальне обстеження хворої людини, яка потребує медичної допомоги; припинення активних заходів щодо підтримання життя хворого у випадку, коли стан людини ще не визначений як незворотна смерть. Ненадання допомоги хворому в конкретній ситуації може поєднуватися з приховуванням винним своєї професії.

Отже, в цьому разі необхідно говорити про встановлений регулятивним законодавством обов'язок, виконання якого забезпечується загрозою настання кримінальної відповідальності. Як доречно зазначає О.І. Бойко, зобов'язує не кримінальний закон, а бланкетний нормативний акт чи посадова інструкція [7, с. 128].

Відповідальність за ст. 139 КК України настає лише за умови, коли особа, яка була зобов'язана надавати хворому допомогу, з урахуванням конкретної обстановки фактично мала таку можливість [8, с. 191].

Під поважними причинами, які виключають відповідальність за ст. 139 КК України, зазвичай розуміються різноманітні обставини, які перешкоджають медичному працівникові надати хворому допомогу, зокрема непереборна сила, стан крайньої необхідності (наприклад, необхідність надати першочергову допомогу більш тяжкохворій особі), хвороба самого медичного працівника, відсутність для надання конкретного виду допомоги кваліфікації, знань, обладнання чи ліків (якщо медичним працівником вжито заходів щодо виклику належного фахівця).

Об'єктивна сторона злочину, передбаченого ст. 140 КК України, характеризується 
діянням (дією чи бездіяльністю), тобто невиконанням чи неналежним виконанням медичним або фармацевтичним працівником своїх професійних обов'язків внаслідок недбалого чи несумлінного до них ставлення наслідками у вигляді тяжких наслідків для хворого; причинним зв'язком між зазначеним діянням та наслідками. Невиконання професійних обов'язків означає, що медичний або фармацевтичний працівник не вчиняє тих дій, яких він з огляду на професійні обов'язки зобов'язаний був вчинити. Неналежне виконання професійних обов'язків має місце тоді, коли медичний або фармацевтичний працівник виконує свої обов'язки не в повному обсязі, недбало, поверхово, не так, як цього вимагають інтереси його професійної діяльності.

За ст. 140 КК України можуть кваліфікуватися, зокрема, такі діяння, як несвоєчасний або неправильний діагноз захворювання; залишення хворого без належного медичного догляду; переливання крові іншої групи, неправильний вибір часу та обсягу проведення операції; залишення сторонніх предметів в організмі хворого під час хірургічної операції; застосування неправильного лікування; недостатній контроль за медичною технікою; порушення правил виготовлення, зберігання або застосування лікарських засобів; не встановлення належного лікувально-охоронюваного режиму для хворих які страждають на психічні розлади; невиконання медсестрою вказівки лікаря щодо застосування до хворого ліків чи процедур; зараження інфекційною хворобою під час хірургічного втручання, переливання крові або трансплантації органу [9, с. 36-37].

3 огляду на те, що диспозиція ст. 140 КК України має бланкетний характер, у кожному випадку їі застосування необхідно встановлювати, які саме професійні обов'язки покладались на винну особу та які 3 цих обов'язків не виконані взагалі або виконані неналежним чином, а також вимоги яких конкретно нормативних актів (інструкцій, правил, вказівок тощо) порушено винним $[10$, c. 100$]$.

3 точки зору кваліфікації за ст. 140 КК України причинний зв'язок як ознака об'єктивної сторони передбаченого цією статтею складу злочину може бути як прямим, тобто безпосереднім (наприклад, у випадку ін'єкції лікарського засобу, що $€$ неприйнятним для певного пацієнта), так і опосередкованим, а саме ускладнятися необережною поведінкою самого потерпілого та іншими чинниками, включаючи природний несприятливий розвиток хвороби й винну діяльність декількох суб'єктів.
Злочин вважається закінченим з моменту настання тяжких наслідків для хворого. До тяжких наслідків злочину, що розглядається, належать тяжкі тілесні ушкодження, смерть пацієнта.

Щоби диференціювати кримінальну відповідальність залежно від тяжкості наслідків, вбачається доцільним доповнити диспозицію ч. 2 ст. 140 КК України шляхом її викладення в такій редакції: «Те саме діяння, якщо воно спричинило тяжкі наслідки неповнолітній особі або двом чи більше особам, карається...».

Об'єктивна сторона злочину, передбаченого ст. 141 КК України, полягає в проведенні клінічних випробувань лікарських засобів без письмової згоди пацієнта або його законного представника чи стосовно неповнолітньої або недієздатної особи, якщо ці дії спричинили смерть пацієнта або інші тяжкі наслідки.

Отже, за конструкцією об’єктивної сторони складу злочину діяння, передбачене ст. 141 КК України, належить до злочинів 3 матеріальним складом. Закінченим злочин вважається 3 моменту настання передбачених наслідків. Об'єктивну сторону діяння утворюють активна дія з клінічних випробувань, вчинених без отримання у пацієнта, його законного представника або близького родича письмової інформованої згоди на участь у такому дослідженні [11].

Об'єктивна сторона злочину, передбаченого ст. 142 КК України, характеризується, зокрема, діями у вигляді незаконного проведення медико-біологічних, психологічних або інших дослідів над людиною; наслідками у вигляді створення небезпеки для іï життя чи здоров'я; причинним зв'язком між зазначеними діями й наслідками. Кваліфікуючими ознаками цього злочину є вчинення його щодо неповнолітньої особи; щодо двох або більше осіб; шляхом примушування або обману; спричинення тривалого розладу здоров'я потерпілого.

3 об'єктивної сторони злочин, передбачений ст. 143 КК України, може набувати такого вигляду: умисне порушення встановленого законом порядку застосування трансплантації анатомічних матеріалів людини (ч. 1 ст. 143 КК України); вилучення у людини шляхом примушування або обману їі анатомічних матеріалів задля їх трансплантації (ч. 2 ст. 143 КК України); дії, передбачені частиною другою цієї статті, вчинені щодо особи, яка перебувала в безпосередньому стані або в матеріальній чи іншій залежності від винного (ч. 3 ст. 143 КК України); незаконна торгівля анатомічнимиматеріаламилюдини(ч.4ст.143КК 
України); дії, передбачені частинами другою, третьою чи четвертою цієї статті, вчинені за попередньою змовою групою осіб, або участь у транснаціональних організаціях, які займаються такою діяльністю (ч. 5 ст. 143 КК України) [12, с. 95-96].

Об’єктивна сторона злочину, передбаченого ст. 144 КК України, полягає в протиправному вилученні крові у людини проти іiї волі, вчиненому шляхом застосування до неї насильства чи за її згодою, але внаслідок обману. Кваліфікуючими ознаками цього злочину є вчинення його щодо неповнолітньої особи або особи, яка перебувала в безпорадному стані чи в матеріальній залежності від винного, а також вчинення дії, передбаченої ч. ч. 1, 2 ст. 144 КК України, за попередньою змовою групою осіб або задля продажу. Аналізуючи назву ст. 144 КК України, маємо зазначити, що вона не узгоджується зі способами вчинення злочину, передбаченого цією статтею.

Об'єктивна сторона злочину, передбаченого ст. 145 КК України, полягає в розголошенні лікарської таємниці особою, якій вона стала відома у зв'язку з виконанням службових чи професійних обов'язків, якщо таке діяння спричинило тяжкі наслідки (самогубство, нервовий стрес, іншу тяжку хворобу потерпілого). Розголошення відбувається 3 прямим умислом, а спричинення шкоди життю чи здоров'ю може бути як з умислом, так і через необережність. Спричинення шкоди честі, гідності та волі особи є завжди, навіть якщо не спричиняються тяжкі наслідки й діяння не є кримінально караним [2, с. 415].

Здійснивши всебічний юридичний аналіз ознак об'єктивної сторони складів злочинів, які вчиняються медичним або фармацевтичним працівником у сфері професійної діяльності, бачимо, яке велике значення вона має для правильної кваліфікації конкретного злочину; відмежування одного злочину від іншого, а також від адміністративних правопорушень

\section{Висновки}

Отже, можна виділити злочини, що посягають на права особи у сфері медичної діяльності виключно дією (ст. ст. 131, 134, 142, ч. ч. 2-4 ст. 143 КК України), й такі, що можуть бути вчинені альтернативно дією чи бездіяльністю (ст. ст. 132, 145, 139, 140, ч. 1 ст. 143 КК України). Зроблено висновок, що об'єктивній стороні деяких посягань на правопорядок у сфері медичної діяльності властива «змішана бездіяльність», коли без акту бездіяльності дії особи не мають значення в об'єктивній стороні злочину, й навпаки (ст. ст. 138, 141, 144 КК України). Сформульовано рекомендації щодо кваліфікації таких злочинів з урахуванням зазначених особливостей.

Доведено, що об'єктивна сторона складу злочину має велике значення для правильної кваліфікації конкретного злочину; відмежування одного злочину від іншого, а також від інших правопорушень, насамперед адміністративних; правильного визначення 3 урахуванням пом'якшуючих та обтяжуючих обставин, які виявляються під час дослідження саме цієї сторони, ступеня тяжкості вчиненого злочину, зрештою, постановлення справедливого судового вироку.

\section{Список використаних джерел:}

1. Баулін Ю.В., Борисов В.І., Гавриш С.Б. та ін. Кримінальне право України : Особлива частина : підручник / за ред. В.В. Сташиса, В.Я. Тація. 3-те вид., перероб. і допов. Київ : Юрінком Інтер, $2007.624 \mathrm{c}$.

2. Кримінальний кодекс України : науковопрактичний коментар / за заг. ред. О.М. Джужі, А.В. Савченка, В.В. Чернєя. Київ : Юрінком Інтер, 2018. $1064 \mathrm{c}$.

3. Горпинюк О.П. Кримінально-правова охорона інформаційного аспекту приватності : автореф. дис. ... канд. юрид. наук : спец. 12.00.08. «Кримінальне право та кримінологія; кримінально-виконавче право». Львів, 2011. 19 с.

4. Байлов А.В., Черевко К.О. Відмежування незаконного проведення аборту від суміжних складів злочинів. 10 років чинності Кримінального кодексу України: проблеми застосування, удосконалення та подальшої гармонізамії із законодавством європейських краӥн : матеріали міжнародної науково-практичної конференції, 13-14 жовтня 2011 р. / редкол.: В.Я. Тацій (голов. ред.), В.І. Борисов (заст. голов. ред.) та ін. Харків : Право, 2011. С. 412-415.

5. Глушков В.А. Ответственность за преступления в области здравоохранения. Киев : Вища школа, 1987. 198 с.

6. Соловйов А.В. До питання співвідношення понять права людини на життя та права на охорону здоров'я і медичну допомогу. Підприємниитво, господарство і право. 2002. № 10. С. 38-40.

7. Бойко А.И. Преступное бездействие. Санкт-Петербург : Юридический центр Пресс, 2003. $320 \mathrm{c}$.

8. Крупко Д.І. Встановлення обов'язку надати медичну допомогу в контексті ст. 139 КК. Правова держава. 2010. № 12. С. 188-193.

9. Балабко В.В. Вчинення злочинів медичними та фармацевтичними працівниками: ненадання медичної допомоги хворому та неналежне виконання професійних обов'язків: аналіз складів злочину. Вісник прокуратури. 2010. № 5. С. 34-44.

10. Яремко Г.З. Бланкетні диспозиції в статтях Особливої частини Кримінального кодексу України : монографія / за ред. В.О. Навроцького. 
Львів : Львівський державний університет внутрішніх справ, 2011. 432 c.

11. Класифікатор професій ДК 003:2005 Наказ Державного комітету України з питань технічного регулювання та споживчої політики від
26 грудня 2005 р. № 375. URL: http://zakon2.rada. gov.ua/laws/show/vc375609.05.

12. Балабко В.В. Вчинення злочинів медичними працівниками у сфері трансплантації: окремі питання. Бюлетень Міністерства юстииї Украйни. 2010. № 2. C. $90-97$.

The article explores the objective side of the crimes under Art. Art.131,132, 134, 139-145 of the Criminal Code of Ukraine. Attention is drawn to the fact that it is precisely because of the features of the objective side that the object and the subjective (internal) side of the crime are determined. The features of the objective side of the crime warehouses are specified in relation to certain articles of the Special Part of the Criminal Code of Ukraine, which provide for criminal liability of a medical or pharmaceutical employee for committing a crime related to the performance of professional duties. The crimes that violate the rights of a person in the sphere of medical activity solely by action (art. 131, 134, 142, h. 2-4, art. 143 of the Criminal Code of Ukraine), and those that can be committed by alternative action or omission (art. Article 132, 145, 139, 140, Part 1 of Article 143 of the Criminal Code of Ukraine). It is concluded that the objective side of some encroachments on the rule of law in the sphere of medical activity is characterized by "mixed inaction", when without the act of inactivity the actions of the person are irrelevant in the objective side of the crime and vice versa (Articles 138, 141, 144 of the Criminal Code Ukraine). Recommendations have been formulated on the qualification of such crimes, taking into account the specific features. It is determined that on the objective side, the crime under Art. 139 of the Criminal Code of Ukraine, expressed in inactivity, because a medical professional, who in accordance with the established rules is obliged to provide care to the patient, without good reason does not do so. Inaction in criminal law usually refers to the socially dangerous willful behavior of a person, which is to fail to perform his or her due - that duty which the person should and could fulfill. Failure to provide assistance to the patient can be expressed both in complete refusal to provide it and in the absence of assistance in the amount required in a particular situation. It is concluded that the objective side of the crime is important for the proper qualification of a particular crime; separating one crime from another, as well as from other administrative offenses, first of all; the correct determination, taking into account the mitigating and aggravating circumstances that are revealed in the investigation of this particular party, the severity of the crime committed and, ultimately, the issuance of a fair judgment.

Key words: socially dangerous act, socially dangerous consequences, causal relationship, place, time, situation, method, means and tools of committing a crime. 